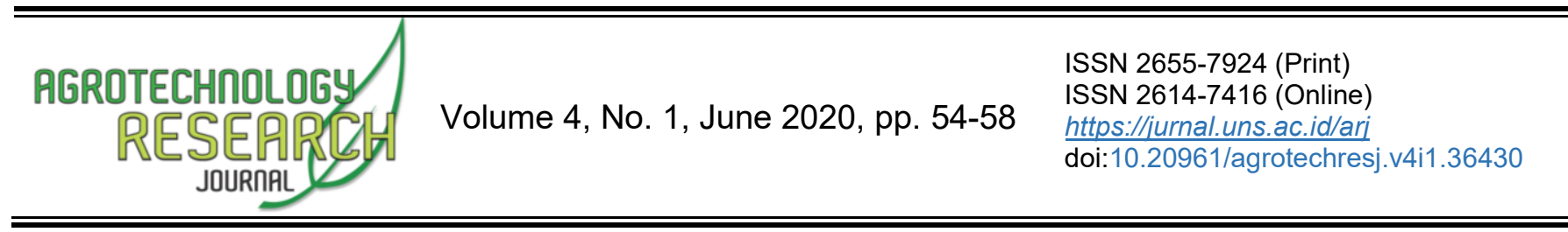

\title{
Respon Kedelai Hitam terhadap Berbagai Jenis Pupuk Organik
}

\author{
Andi Ralle ${ }^{1}$, St Subaedah ${ }^{*}$ \\ ${ }^{1-2}$ Department of Agrotechnology, Faculty of Agriculture, Universitas Muslim Indonesia, Makassar, Indonesia
}

Received 2 December 2019; Accepted 27 May 2020; Published 25 June 2020

\begin{abstract}
Increased productivity of black soybeans continues to be pursued by improving appropriate cultivation technologies, including by providing organic fertilizer. This research aimed to assessing the response of growth and production of black soybean plants to various types of organic fertilizers. The study was conducted in the form of a field experiment in Gowa Regency from March-June 2019. The experiment was designed with a randomized completed block design consisting of four treatments, namely: without organic fertilizer, organic fertilizer from rice straw, organic fertilizer from banana stems and organic fertilizer from gamal leaves. Each treatment was repeated four times, so as to get 16 experimental units. The parameters observed were plant height, number of pods per plant, pod weight per plant and pod weight per plot. The results showed that the administration of organic fertilizers obtained better growth and production of black soybeans. Fertilization with organic fertilizer from Gamal leaves obtained the highest yield of black soybean seeds, 2.46 tons ha $^{-1}$.
\end{abstract}

Keywords: Banana stems; Gamal leaves; Rice straw

Cite This As (CSE Style): Ralle A, Subaedah S. 2020. Respon Kedelai Hitam terhadap Berbagai Jenis Pupuk Organik. Agrotech Res J 4(1): 54-58. https://doi.org/10.20961/agrotechresj.v4i1.36430

\section{PENDAHULUAN}

Di Indonesia terdapat berbagai jenis kedelai yaitu kedelai putih, kuning, agak putih, hijau dan kedelai berbiji hitam (Adie dan Krisnawati 2007). Namun kedelai hitam tidak terlalu populer dibandingkan kedelai kuning. Kedelai hitam sangat bermanfaat sebagai bahan makanan sehat atau industri kecap yang berkualitas tinggi karena mengandung antosianin. Kandungan antosianin yang tinggi mempunyai aktivitas antioksidan yang besar (Dornbos Jr. dan Mullen 1991; Nurrahman 2015). Produksi kedelai di Indonesia hanya mencukupi sekitar 35\% kebutuhan (Aldillah 2015). Oleh karena itu perlu adanya usaha perbaikan teknik budidaya untuk meningkatkan produksi dan produktivitas kedelai hitam.

Usaha peningkatan produksi kedelai hitam dengan perbaikan teknik budidaya, misalnya dengan pemupukan yang tepat. Pemupukan dapat dilakukan dengan pupuk anorganik maupun pupuk organik. Pemupukan anorganik yang terus menerus tanpa diimbangi dengan pemberian pupuk organik akan mengakibatkan degradasi lahan, yang ditandai dengan rendahnya kadar bahan organik tanah dan rendahnya ketersediaan hara bagi tanaman. Menurut Sugito et al. (1995) kadar bahan organik di dalam tanah di lahanlahan pertanian sangat rendah yakni kurang dari $2 \%$,

${ }^{*}$ Corresponding Authors:

1E-Mail: st.subaedah@umi.ac.id sedangkan untuk mencapai produktivitas optimal dibutuhkan kadar bahan organik tanah $>2,5 \%$. Bahan organik merupakan kunci dalam memperbaiki kesuburan tanah (Samosir, 2000). Oleh karena itu, dalam pembudidayaan tanaman diperlukan usaha untuk meningkatkan kadar bahan organik tanah dengan penggunaan pupuk organik dan mengurangi penggunaan pupuk anorganik.

Berbagai jenis bahan organik yang dapat dijadikan sebagai pupuk organik, seperti misalnya jerami padi, batang pisang, daun gamal dan lain-lain. Penggunaan pupuk organik akan meningkatkan kandungan bahan organik tanah yang akan memperbaiki kesuburan tanah dan selanjutnya memperbaiki pertumbuhan dan meningkatkan produksi tanaman (Oviyanti dan Hidayah 2016; Subaedah et al. 2019). Di samping itu bahan organik berfungsi sebagai perekat yang akan meningkatkan kemantapan struktur tanah dan meningkatkan kemampuan tanah menahan air, sehingga ketersediaan air tanah bagi tanaman akan meningkat (Resosudarmo et al. 2019). Setiap bahan organik memiliki sifat yang berbeda sehingga dapat memberikan pengaruh yang berbeda. Kebaharuan penelitian ini adalah penggunaan berbagai sumber pupuk organik yaitu jerami padi, batang pisang dan daun gamal sebanyak 20 ton/ha untuk meningkatkan produksi kedelai hitam. Berdasarkan uraian tersebut, penelitian bertujuan untuk mengkaji respon tanaman kedelai hitam terhadap pemberian berbagai jenis pupuk organik. 


\section{BAHAN DAN METODE}

Penelitian ini dilaksanakan di lahan kering Kabupaten Gowa pada bulan Maret sampai Juni 2019. Bahan yang digunakan yaitu benih kedelai hitam varietas Detam 1 , bokashi jerami padi, bokashi batang pisang dan bokashi daun gamal, label, pupuk kandang, pupuk urea, SP-36, $\mathrm{KCl}$, pestisida dan fungisida. Alat yang digunakan yaitu timbangan, meter, mistar geser, dan lain-lain.

Penelitian dirancang dengan Rancangan Acak Kelompok yang terdiri dari empat perlakuan pemupukan yaitu:

$\mathrm{P0}$ : tanpa pupuk organik (kontrol)

$\mathrm{P} 1$ : pupuk organik dari jerami padi

$\mathrm{P} 2$ : pupuk organik dari batang pisang

P3 : pupuk organik dari daun gamal

Setiap perlakuan diulang sebanyak 4 kali sehingga diperoleh 16 satuan percobaan.

Pelaksanaan penelitian dimulai dengan pengolahan tanah, pembuatan blok, pembuatan 4 petak perlakuan dengan ukuran $3 \mathrm{~m} \times 2 \mathrm{~m}$, aplikasi pupuk organik. Pupuk organik diaplikasikan sesuai perlakuan masing-masing dengan dosis 20 ton/ha. Penanaman dilaksanakan satu minggu setelah pemberian pupuk organik dengan jarak tanam $40 \mathrm{~cm} \times 20 \mathrm{~cm}$. Penyiangan dilakukan pada saat tanaman berumur 20 dan 40 hari setelah tanam. Parameter yang diamati yaitu tinggi tanaman, jumlah polong per tanaman, bobot polong per tanaman, bobot polong per petak dan dikonversi per ha. Data hasil penelitian dianalisis dengan menggunakan ANOVA dan uji lanjut dengan uji Beda Nyata Terkecil taraf $5 \%$.

\section{HASIL DAN PEMBAHASAN Tinggi tanaman}

Hasil penelitian menunjukkan bahwa pemberian berbagai jenis pupuk organik tidak berpengaruh nyata terhadap tinggi tanaman kedelai hitam pada umur 8 minggu setelah tanam (MST). Gambar 1 menunjukkan pupuk organik batang pisang menghasilkan tanaman yang lebih tinggi $(88,77 \mathrm{~cm})$ dibandingkan dengan perlakuan lainnya. Tinggi tanaman merupakan salah satu indikator pertumbuhan tanaman. Pengaruh pupuk organik terhadap tinggi tanaman disebabkan karena pupuk organik mampu menyuplai kebutuhan hara yang dibutuhkan tanaman. Penambahan pupuk organik mampu meningkatkan bahan organik dan memperbaiki sifat fisik tanah, serta meningkatkan kemantapan agregat dan porositas tanah (Zulkarnain et al. 2013). Bahan organik tanah merupakan salah satu bahan pembentuk agregat tanah, yang mempunyai peran sebagai bahan perekat antar partikel tanah menjadi agregat tanah, sehingga bahan organik penting dalam perbaikan sifat fisik tanah (Buckman dan Brady 1980). Kondisi fisik tanah berperan dalam penetrasi akar, penyerapan air dan hara (Roy et al. 2013). Berdasarkan hasil penelitian de Albuquerque Nunes et al. (2015) bahwa pupuk organik dapat mengubah kesuburan tanah dengan meningkatkan $\mathrm{pH}, \mathrm{Ca}, \mathrm{Mg}, \mathrm{K}, \mathrm{P}$ sehingga pertumbuhan dan hasil kedelai meningkat.

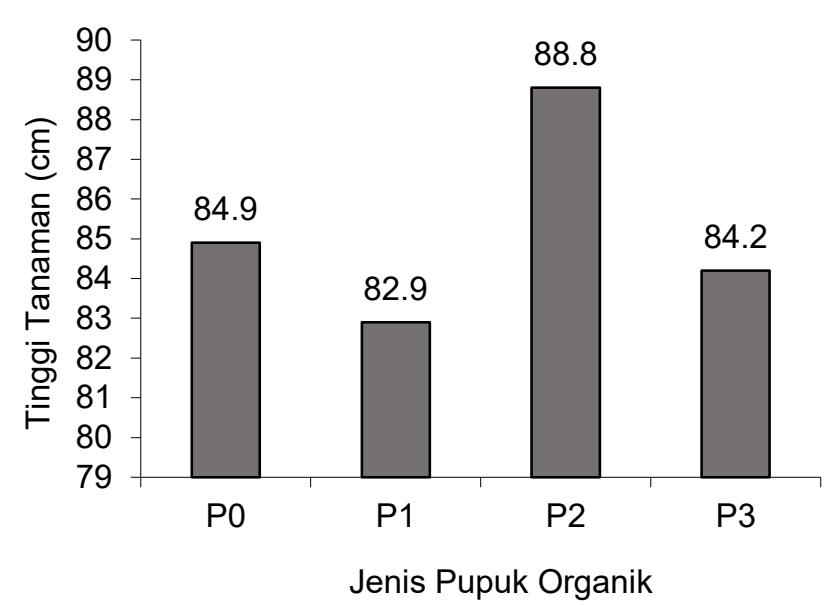

Gambar 1. Tinggi tanaman kedelai hitam dengan pemberian berbagai jenis pupuk organik

\section{Jumlah polong per tanaman}

Hasil penelitian menunjukkan berbagai jenis pupuk organik tidak berpengaruh terhadap jumlah polong per tanaman. Gambar 2 menunjukkan bahwa jumlah polong tertinggi pada aplikasi pupuk organik batang pisang dengan jumlah polong yang dihasilkan 71,56 polong. Biji kedelai terbungkus dalam polong, sehingga parameter jumlah polong merupakan salah satu parameter komponen produksi. Semakin banyak polong yang terbentuk semakin besar produksi yang dapat dicapai. Hasil penelitian ini sejalan dengan Adeli et al. (2005) bahwa aplikasi pupuk organik mampu jumlah polong kedelai sebesar $3 \%$ dibandingkan dengan aplikasi pupuk kimia. Peningkatan jumlah polong berkorelasi positif dengan jumlah biji yang dihasilkan (Slaton et al. 2013).

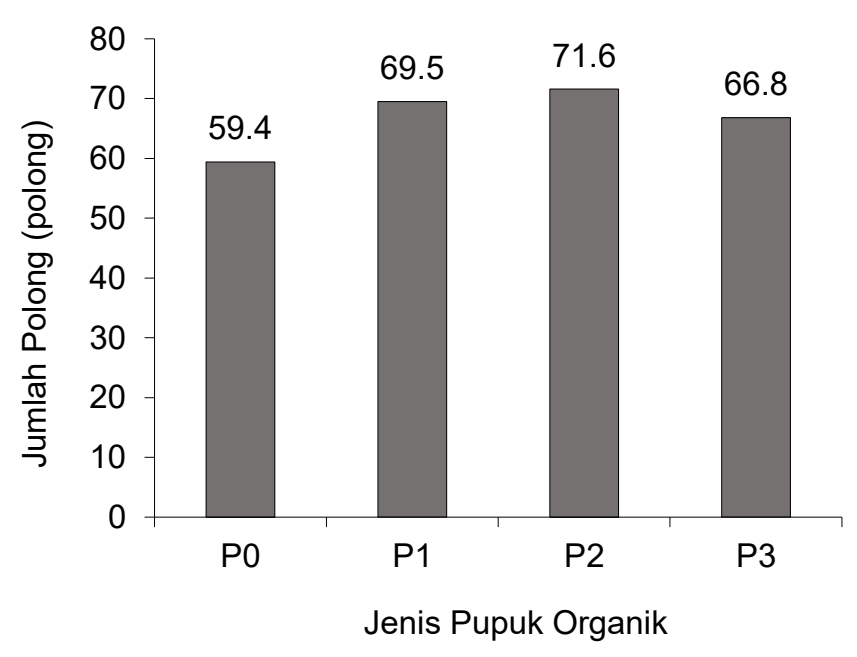

Gambar 2. Jumlah polong kedelai hitam dengan pemberian berbagai jenis pupuk organik

\section{Bobot polong per tanaman}

Hasil penelitian menunjukkan bahwa berbagai jenis pupuk organik berpengaruh signifikan terhadap bobot polong per tanaman. Hasil uji lanjut menunjukkan bahwa bobot polong per tanaman tertinggi pada perlakuan pupuk organik daun gamal $(39,64 \mathrm{~g})$. Bobot polong per 
tanaman pada perlakuan pupuk organik daun gamal berbeda nyata dengan perlakuan tanpa pupuk organik $(26,17$ g). Aplikasi pupuk organik mendorong pertumbuhan kedelai, meningkatkan hasil dan kualitas kedelai setara dengan aplikasi pupuk kimia (Barbazán et al. 2009). Hal tersebut disebabkan karena pupuk organik memiliki kemampuan memperbaiki sifat kimia tanah. Gamal merupakan salah satu tanaman legum yang memiliki potensi sebagai sumber nutrisi bagi tanaman bila digunakan sebagai pupuk organik. Berdasarkan hasil penelitian Oviyanti and Hidayah (2016) bahwa pupuk organik daun gamal mengandung $0,24 \% \mathrm{~N}$, $0,039 \% \mathrm{P}, 8,38 \% \mathrm{~K}$, organik $\mathrm{C} 12,4 \%$. unsur hara $\mathrm{N}, \mathrm{P}$, dan $\mathrm{K}$ dibutuhkan tanaman untuk proses fisiologi dan metabolisme dalam tanaman yang akan memicu pertumbuhan dan hasil tanaman.

Hasil analisis tanah menunjukkan bahwa pemberian pupuk organik daun gamal mampu meningkatkan kadar C-organik tanah hingga $28 \%$ dibandingkan tanpa pemberian pupuk organik (data tidak disajikan). Hal ini sejalan dengan penelitian yang dilakukan Subaedah et al. (2004) bahwa penggunaan bahan organik dapat memperbaiki sifat kimia tanah seperti: N-total tanah meningkat hingga $60 \%$, kadar bahan organik tanah meningkat hingga $25 \%$ serta meningkatkan KTK tanah hingga $24 \%$ dan pada akhirnya meningkatkan produksi jagung di lahan kering hingga sebesar 50\%.

Tabel 1. Bobot polong kedelai per tanaman (g) dengan pemberian berbagai jenis pupuk organik

\begin{tabular}{lc}
\hline Pupuk Organik & $\begin{array}{c}\text { Bobot Polong per Tanaman } \\
(\mathrm{g})\end{array}$ \\
\hline Tanpa Pupuk & $26,17 \pm 1,90 \mathrm{~b}$ \\
Jerami & $34,89 \pm 7,78 \mathrm{ab}$ \\
Batang pisang & $35,96 \pm 8,96 \mathrm{a}$ \\
Daun gamal & $39,64 \pm 8,25 \mathrm{a}$ \\
\hline
\end{tabular}

Keterangan: angka yang diikuti oleh huruf yang sama berarti tidak berbeda nyata berdasarkan uji BNT taraf 0,05

\section{Bobot biji kedelai per petak}

Hasil penelitian menunjukkan bahwa perlakuan berbagai jenis pupuk organik berpengaruh signifikan terhadap bobot biji kedelai per petak. Pupuk organik daun gamal menunjukkan bobot biji kedelai per petak tertinggi yaitu sebesar 294,77 g (Tabel 2). Hasil tersebut berbeda nyata dengan perlakuan tanpa pupuk organik (P0) yaitu hanya 206,92 g. Hasil penelitian ini sejalan dengan Novriani (2016) pemberian pupuk organik cair dari daun Gamal meningkatkan produksi tanaman kubis bunga. Hal tersebut disebabkan karena gamal (Gliricidia sepium) merupakan salah satu jenis tanaman leguminosae dengan kandungan unsur hara yang tinggi. Gamal yang berumur satu tahun mengandung 3-6\% N; $0,31 \% \mathrm{P} ; 0,77 \% \mathrm{~K} ; 15-30 \%$ serat kasar; dan $10 \%$ abu $\mathrm{K}$ (Alfianati 2017).
Tabel 2. Rata-rata bobot biji kedelai per petak (g) dengan pemberian berbagai jenis pupuk organik

\begin{tabular}{lc}
\hline Pupuk organik & $\begin{array}{c}\text { Bobot biji per petak } \\
(\mathrm{g})\end{array}$ \\
\hline Tanpa Pupuk & $206,92 \pm 19,08 \mathrm{~b}$ \\
Jerami & $279,72 \pm 40,54 \mathrm{a}$ \\
Batang Pisang & $246,95 \pm 80,61 \mathrm{ab}$ \\
Daun Gamal & $294,77 \pm 66,38 \mathrm{a}$ \\
\hline
\end{tabular}

Keterangan: angka yang diikuti oleh huruf yang sama berarti tidak berbeda nyata berdasarkan uji BNT taraf 0,05

\section{Produksi biji kedelai per $\mathrm{Ha}$}

Produksi biji kering kedelai per ha dipengaruhi oleh berbagai jenis pupuk organik. Hasil penelitian menunjukkan bahwa pupuk organik daun gamal (P3) menghasilkan produksi kedelai per ha yang tinggi yaitu 2,46 t. ha: Hasil tersebut berbeda nyata dengan perlakuan tanpa pupuk organik (P0) yaitu hanya $1,72 \mathrm{t}$ ha $^{-1}$. Hasil tersebut menunjukkan bahwa pupuk daun gamal dapat meningkatkan hasil kedelai hitam. Hasil penelitian ini sejalan dengan Wicaksana and Sulistyono (2017) bahwa pupuk organik daun gamal dapat meningkatkan pertumbuhan dan hasil mentimun. Hal tersebut disebabkan karena pupuk daun gamal dapat menyuplai unsur hara yang diperlukan tanaman dalam jumlah yang cukup selama pertumbuhan (Seni et al. 2013). Peningkatan bahan organik dan unsur hara akan mempengaruhi aktivitas organisme dalam tanah sehingga pertumbuhan dan hasil kedelai meningkat (Marzuki et al. 2012).

Tabel 3. Produksi biji kedelai per ha (ton) dengan pemberian berbagai jenis pupuk organik

\begin{tabular}{lc}
\hline Pupuk organik & $\begin{array}{c}\text { Produksi biji kedelai } \\
\left(\mathrm{t} . \mathrm{ha}^{-1}\right)\end{array}$ \\
\hline Tanpa Pupuk & $1,72 \pm 0,16 \mathrm{~b}$ \\
Jerami & $2,33 \pm 0,34 \mathrm{a}$ \\
Batang Pisang & $2,05 \pm 0,67 \mathrm{ab}$ \\
Daun Gamal & $2,46 \pm 0,55 \mathrm{a}$ \\
\hline
\end{tabular}

Keterangan: angka yang diikuti oleh huruf yang sama berarti tidak berbeda nyata berdasarkan uji BNT taraf 0,05

Hasil penelitian juga menunjukkan pengaruh pupuk organik daun gamal terhadap komponen produksi tanaman kedelai yang meliputi: bobot polong per tanaman, bobot biji per petak dan produksi biji kedelai per ha. Hal ini sejalan dengan hasil penelitian Oviyanti dan Hidayah (2016) yang menunjukkan bahwa pemberian pupuk organik dari daun gamal memperbaiki pertumbuhan tanaman sawi yang diperlihatkan oleh parameter tinggi tanaman, jumlah daun dan lebar daun yang lebih besar. Subaedah et al. (2019) aplikasi bahan organik dapat memperbaiki pertumbuhan tanaman kedelai dan meningkatkan hasil tanaman kedelai hingga 2,15 t ha-1. Berdasarkan hasil penelitian Rismawan dan Islami (2018) bahwa kombinasi pupuk organik daun gamal dan pupuk kambing berat kering tanaman, bobot biji, dan hasil per hektar tanaman kedelai. 
Kelebihan pupuk organik daun gamal disebabkan gamal merupakan tanaman dari famili leguminosae yang mempunyai kemampuan untuk memfiksasi $\mathrm{N}_{2}$ dari udara, sehingga mempunyai kandungan bahan organik dan nitrogen yang tinggi. Tanaman kedelai dapat tumbuh baik pada tanah yang kaya bahan organik. Pemberian bahan organik dari tanaman legum dapat memperbaiki sifat tanah, menyuplai bahan organik, meningkatkan nitrogen dan memperbaiki aktivitas jasad renik (Magdalena et al. 2013).

Nitrogen merupakan unsur hara makro primer yang dibutuhkan tanaman dalam jumlah banyak (Ramadhan et al. 2015), sehingga dengan meningkatnya kandungan $\mathrm{N}$ tanah akan memungkinkan pertumbuhan tanaman berjalan maksimal. Daun Gamal mengandung $3,15 \% \mathrm{~N}$, $0,22 \% \mathrm{P}, 2,65 \% \mathrm{~K}, 1,35 \% \mathrm{Ca}$, dan 0,41\% Mg (Alfianati 2017; Yamin et al. 2019). Kandungan N yang tinggi dari daun Gamal dengan rasio $\mathrm{C} / \mathrm{N}$ rendah, memudahkan terjadinya dekomposisi (Yamin et al. 2019). Rasio C/N merupakan salah satu indikator kualitas pupuk organik yang digunakan (Widyantika dan Prijono 2019).

\section{KESIMPULAN DAN SARAN}

1. Pemberian pupuk organik berpengaruh terhadap pertumbuhan dan produksi tanaman kedelai hitam

2. Pemberian pupuk organik dari daun Gamal menghasilkan produksi yang lebih tinggi yaitu mencapai 2,50 ton ha-1.

\section{UCAPAN TERIMA KASIH}

Ucapan terima kasih disampaikan kepada Yayasan Wakaf Universitas Muslim Indonesia yang telah memberikan bantuan biaya sehingga penelitian ini bisa dilaksanakan.

\section{DAFTAR PUSTAKA}

Adeli A, Karamat RS, Dennis ER, Haile T. 2005. and Phosphorus Concentrations. Agron J. 97:314-321.

Adie, M. M. dan Krisnawati, A. 2007. Biologi tanaman kedelai. Balai Penelitian Kacang-kacangan dan Umbi-umbian (BALITKABI). Malang.

de Albuquerque Nunes WAG, Menezes JFS, de Melo Benites V, de Unior SA, Dos Oliveira AS. 2015. Use of organic compost produced from slaughterhouse waste as fertilizer in soybean. Sci Agric. 72(4):343350. doi:10.1590/0103-9016-2014-0094.

Aldillah R. 2015. Proyeksi produksi dan konsumsi kedelai indonesia. Pus Anal Sos Ekon dan Kebijak Pertanian, Kementrian Pertan Republik Indones Abstr.:8 (1): 9-239-23.

Alfianati MWSMW dan. 2017. Pemanfaatan batang pisang sebagai pupuk organik cair dengan metoda fermentasi dengan aktivator EM4 dan lama fermentasi. Jurnal Proton. 8(1):127-135.

Barbazán MM, Mallarino AP, Sawyer JE. 2009. Liquid Swine Manure Phosphorus Utilization for Corn and Soybean Production. Soil Sci Soc Am J. 73(2):654662. doi:10.2136/sssaj2008.0239.
Buckman, H.O. and N.C. Brady. 1980. The Nature and Properties of Soil. 8th Edition. Eurasia Publishing House Ltd. Ram Nagar, New Delhi. 639p.

Dornbos Jr. DL, Mullen RE. 1991. Influence of stress during soybean seed fill on seed weight, germination, and seedling growth rate. Can J Plant Sci. 71(2):373383. doi:10.4141/cjps91-052.

Magdalena F, Sudiarso, dan T. Sumarni. 2013. Penggunaan pupuk kandang dan pupuk hijau Crotalaria juncea $\mathrm{L}$. untuk mengurangi penggunaan pupuk anorganik pada tanaman jagung (Zea mays L.). J Produksi Tanam. 1(2):61-71.

Marzuki M, Sufardi S, Manfarizah M. 2012. Sifat Fisika dan Hasil Kedelai (Glycine max L) pada Tanah Terkompaksi Akibat Cacing Tanah dan Bahan Organik. J Manaj Sumberd Lahan. 1(1):23-31.

Novriani. 2016. Pemanfaatan daun gamal sebagai pupuk organik cair (poc) untuk meningkatkan pertumbuhan dan produksi tanaman kubis bunga (Brassica oleracea I.) pada tanah podsolik. Klorofil. 11(1):15-19. doi:10.1017/CBO9781107415324.004.

Nurrahman N. 2015. Evaluasi Komposisi zat gizi dan senyawa antioksidan kedelai hitam dan kedelai kuning. J Apl Teknol Pangan. 4(3):89-93. doi:10.17728/jatp.v4i3.133.

Oviyanti F, Hidayah N. 2016. Pengaruh pemberian pupuk organik cair daun gamal (Gliricidia sepium (jacq.) kunth ex walp.) terhadap pertumbuhan tanaman sawi (Brassica juncea L.). J Biota. 2(1):6167.

Ramadhan MF, Hidayat C, Hasani S. 2015. Pengaruh aplikasi ragam bahan organik dan FMA terhadap pertumbuhan dan hasil tanaman cabai (Capsicum annum L.) varietas landung pada tanah pasca galian C. J Agro. 2(2):50-57. doi:10.15575/438.

Resosudarmo IAP, Tacconi L, Sloan S, Hamdani FAU, Subarudi, Alviya I, Muttaqin MZ. 2019. Indonesia's land reform: Implications for local livelihoods and climate change. For Policy Econ. 108(April):101903. doi:10.1016/j.forpol.2019.04.007.

Rismawan SF, Islami ASK dan T. 2018. The effect of organic matters type on growth and yield of soybean (Glycine max (L.) Merrill). J Produksi Tanam. 6(7):1543-1548.

Roy M, Karmakar S, Debsarcar A, Sen PK, Mukherjee J. 2013. Application of rural slaughterhouse waste as an organic fertilizer for pot cultivation of solanaceous vegetables in India. Int $\mathrm{J}$ Recycl Org Waste Agric. 2(1):1-11. doi:10.1186/2251-7715-2-6.

Samosir, S.S.R. 2000. 2000. Pengelolaan lahan kering. Program Pasca Sarjana Universitas Hasanuddin, Makassar. 203p.

Seni I, Atmaja I, Sutari N. 2013. Analisis Kualitas Iarutan mol (Mikoorganisme Lokal) berbasis daun gamal (Gliricidia Sepium). E-Jurnal Agroekoteknologi Trop (Journal Trop Agroecotechnology). 2(2):135-144. 
Slaton NA, Roberts TL, Golden BR, Jeremy Ross W, Norman RJ. 2013. Soybean response to phosphorus and potassium supplied as inorganic fertilizer or poultry litter. Agron J. 105(3):812-820. doi:10.2134/agronj2012.0490.

Subaedah S, Guritno b, Syamsulbahri, Sastrosupadi a. 2004. Respon tanaman jagung dan perbaikan sifat kimia tanah pada beberagai jenis tanaman penutup di lahan kering. Agrivita 26 (3): 222-226.

Subaedah S, Ralle A, Sabahannur S. 2019. Phosphate fertilization efficiency improvement with the use of organic fertilizer and its effect on soybean plants in dry land. Pakistan J Biol Sci. 22(1):28-33. doi:10.3923/PJBS.2019.28.33.

Sugito, Y., Y. Nuraini dan E. Nihayati. 1995. Sistem pertanian organik. Fakultas Pertanian Universitas Brawijaya, Malang. 84p.
Wicaksana PC, Sulistyono NBE. 2017. Aplikasi pupuk kandang ayam dan mikroorganisme lokal (MOL) daun gamal terhadap produksi dan mutu benih mentimun (Cucumis sativus L.). Agriprima, J Appl Agric Sci. 1(1):72-85. doi:10.25047/agriprima.v1i1.8

Widyantika SD, Prijono S. 2019. Pengaruh biochar sekam padi dosis tinggi terhadap sifat fisisk tanah dan pertumbuhan tanaman jagung pada typic kanhapludult. Tanah dan Sumberd Lahan. 6(1):1145-1156. doi: 10.21776/ub.jtsl.2019.00.

Yamin M, Hairuddin R, Thamrin NT, Suddartik E. 2019. Phenotypic performance of kanesia-10 cotton (Gossypium hirsutum L.) variety through the use of liquid organic fertilizers in low land. Agrotech J. 4(1):38-44. doi:10.31327/atj.v4i1.917.

Zulkarnain M, Prasetya B, Soemarno. 2013. Pengaruh kompos, pupuk kandang, dan custom-bio terhadap sifat tanah, pertumbuhan dan hasil tebu (Saccharum officinarum L.) pada entisol di kebun Ngrakah-Pawon, Kediri. Indones Green Technol J. 2(1):45-52. 